\title{
Analyze the Influence of Information Asymmetric Management on the Lending Performance of the Commercial Banks in Rwanda.
}

Mukasafari Chantal, G. S. Namusonge, Jaya Shukla

To Link this Article: http://dx.doi.org/10.6007/IJARBSS/v11-i5/9892

DOI:10.6007/IJARBSS/v11-i5/9892

Received: 04 March 2021, Revised: 07 April 2021, Accepted: 26 April 2021

Published Online: 17 May 2021

In-Text Citation: (Chantal et al., 2021)

To Cite this Article: Chantal, M., Namusonge, G. S., \& Shukla, J. (2021). Analyze the Influence of Information Asymmetric Management on the Lending Performance of the Commercial Banks in Rwanda. International Journal of Academic Research in Business and Social Sciences, 11(5), 171-189.

Copyright: (c) 2021 The Author(s)

Published by Human Resource Management Academic Research Society (www.hrmars.com)

This article is published under the Creative Commons Attribution (CC BY 4.0) license. Anyone may reproduce, distribute, translate and create derivative works of this article (for both commercial and non-commercial purposes), subject to full attribution to the original publication and authors. The full terms of this license may be seen at: http://creativecommons.org/licences/by/4.0/legalcode

Vol. 11, No. 5, 2021, Pg. 171 - 189

Full Terms \& Conditions of access and use can be found at http://hrmars.com/index.php/pages/detail/publication-ethics 


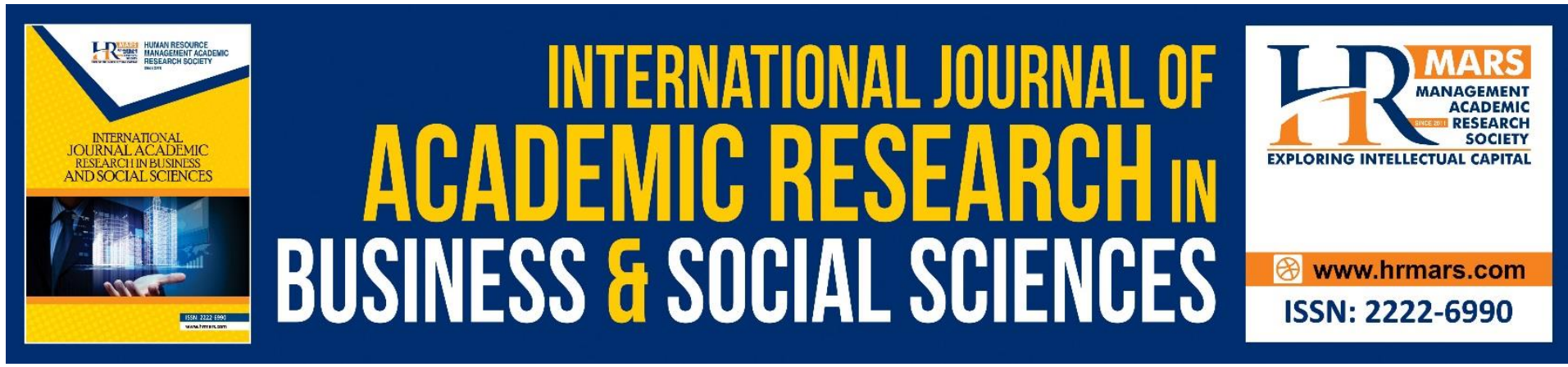

\title{
Analyze the Influence of Information Asymmetric Management on the Lending Performance of the Commercial Banks in Rwanda.
}

\section{Mukasafari Chantal}

PHD candidate, Department of Economics, Accounting and Finance in the School of Business, in partial fulfillment for the award of the degree of Doctor of Philosophy in Business Administration of the Jomo Kenyatta University of Agriculture and Technology.

\section{Prof. G. S. Namusonge}

Jomo Kenyatta University of Agriculture and Technology / Nairobi-Kenya.

Email: gsnamusonge@gmail.com

\section{Dr Jaya Shukla}

Jomo Kenyatta University of Agriculture and Technology /Kigali-Rwanda.

Email: js.jayashukla@gmail.com

\begin{abstract}
To analyze the Influence of Information asymmetric management on the Lending Performance of Commercial Banks in Rwanda. This study is important to various stakeholders in particular the Government of Rwanda, academicians, professionals, and researchers. In this thesis, the researcher aimed at developing the notion conceptually, specifically, built on the work of (Chepkoech \& Francis, 2014) and (Rannenberg, 2012), whom their works were based on the Information asymmetric in credit markets, bank leverage cycles, and macroeconomic dynamics. Two critical aspects formed the guiding philosophy of the entire research process and these were: (1) the Role of Financial institutions on maintaining the monetary stability and the Political factor as the monetary regulator both as the fundamental actors of Lending Performance of Commercial Banks. The study adopted a descriptive survey as study design. The target population of the study was 931 from Bank of Kigali, Bank Populaire du Rwanda, I \&M Bank, Cogebanque, Ecobank, KCB, Equity, GT-Bank, Access Bank, and CraneBank (BCR) where 280 Questionnaires were distributed to selected individuals through stratified and purposive sampling methods and different individuals such as DGs, CEOs, Directors, Head of Units, Specialists, Experts, Professionals from Rwanda were part of the study. The primary data was collected through structured questionnaires; whereas secondary data through reading and analysis of relevant books, reports and journals. The data collected was edited, coded, and fed into SPSS software v. 16 and e-views 3 for analysis, using descriptive, inferential statistics and econometrics. Regression analysis was done to investigate the
\end{abstract}


relationship between hypothesized variables. The study found out that Propitious Selection management has a strong influence on the lending performance of Commercial Banks in Rwanda; where it contributes $(B=0.970)$ on Working Capital $(W C)$ and $(B=0.708)$ on Retained Earnings (RE); Political Drive as a moderating variable plays a positive role on the influencing the Information asymmetric management and on the lending performance of Commercial Banks in Rwanda; where it was influenced $(b=0.783)$ for Working Capital (WC) and $(B=0.789)$ on Retained Earnings (RE); moral hazard management to has a significant influenced the lending performance of Commercial Banks in Rwanda on $(B=0.899)$ for Working Capital (WC) and $(B=0.601)$ on Retained Earnings (RE); however, on the lending performance of Commercial Banks in Rwanda; adverse selection management demonstrates a weak influence on the lending performance of Commercial Banks in Rwanda with $(B=.542)$ on Working Capital $(\mathrm{WC})$ and $(B=.500)$ on Retained Earnings (RE). On conclusion, the researched found out that Information asymmetric management has a statistically significant contribution to the lending performance of Commercial Banks in Rwanda

\section{Introduction}

\section{Background}

- At the global perspective, the component of information asymmetry initiated in 1970.It has become a valuable tool in field of economic and Finance, and it demonstrated a tangible impact since 2000. Because of development of introduction of information technology, many services are done with less manpower like electronic payment, security investment, information exchange and products in transaction. Asymmetric information was useful tool designed to help in the management and control of the corporate financial in Spain. Tunisian companies affect exports at low level of cost due to information.

- At the continental perspective, concept of information asymmetry goes back to the colonialism and in this time commercial banks have issues of surplus liquidity.According to the report of word bank (2015) all continents of word the poverty has been decreasing except Africa because of consequence of colonialism. And For Jappeli \& Pagano,2002 information asymmetry should be managed in Africa between lenders and borrowers.

- At the regional perspective, is about East African Community (EAC). Region members of EAC (Burundi, Kenya, Rwanda, Tanzania, Uganda ) have been starting the business forecast information which play a vital role in the commercial banks operating in Rwanda, and people consider it as the life blood of a growing economy.

- At the national perspective, According to Muyombano,2018, after genocide, Rwanda has envisaged a set of national policies which the goal of transforming the agrarian subsistence economy into a sophisticated knowledge-based society. This was a great achievement exemplary for performance in economy, social and political affairs supported by its vision 2020 set to respond on different components of information asymmetry. For National Bank of Rwanda 2015 and MINECOFIN 2000,the commercial Banks of Rwanda have improved $72 \%$ of Rwandan $42 \%$ in Formal Financial System and $58 \%$ in informal financial system.

\section{Statement of the Problem}

- Campbell (2007) indicates that Rwanda has the highest level of NPLs (Non Performing Loan) compared to the rest of the East African States. 


\section{Research Objectives \\ General Objective}

The general objective of the study is to analyze the influence of information asymmetric management on the lending performance of Commercial Banks in Rwanda.

\section{Specific Objectives}

The specific objectives of the study are

- To assess the influence of moral hazard management on lending performance of Commercial Banks in Rwanda.

- To demonstrate the importance of adverse selection management on the lending performance of Commercial Banks in Rwanda.

- To understand the contribution of Propitious Selection management on the lending performance of Commercial Banks in Rwanda.

- To analyse the moderating effect of political drive on the influence of information asymmetric management and lending performance of Commercial Banks in Rwanda.

\section{Conceptual framework}

Independent Variable

\section{Dependent Variable}

\section{Asymmetric Information Management}

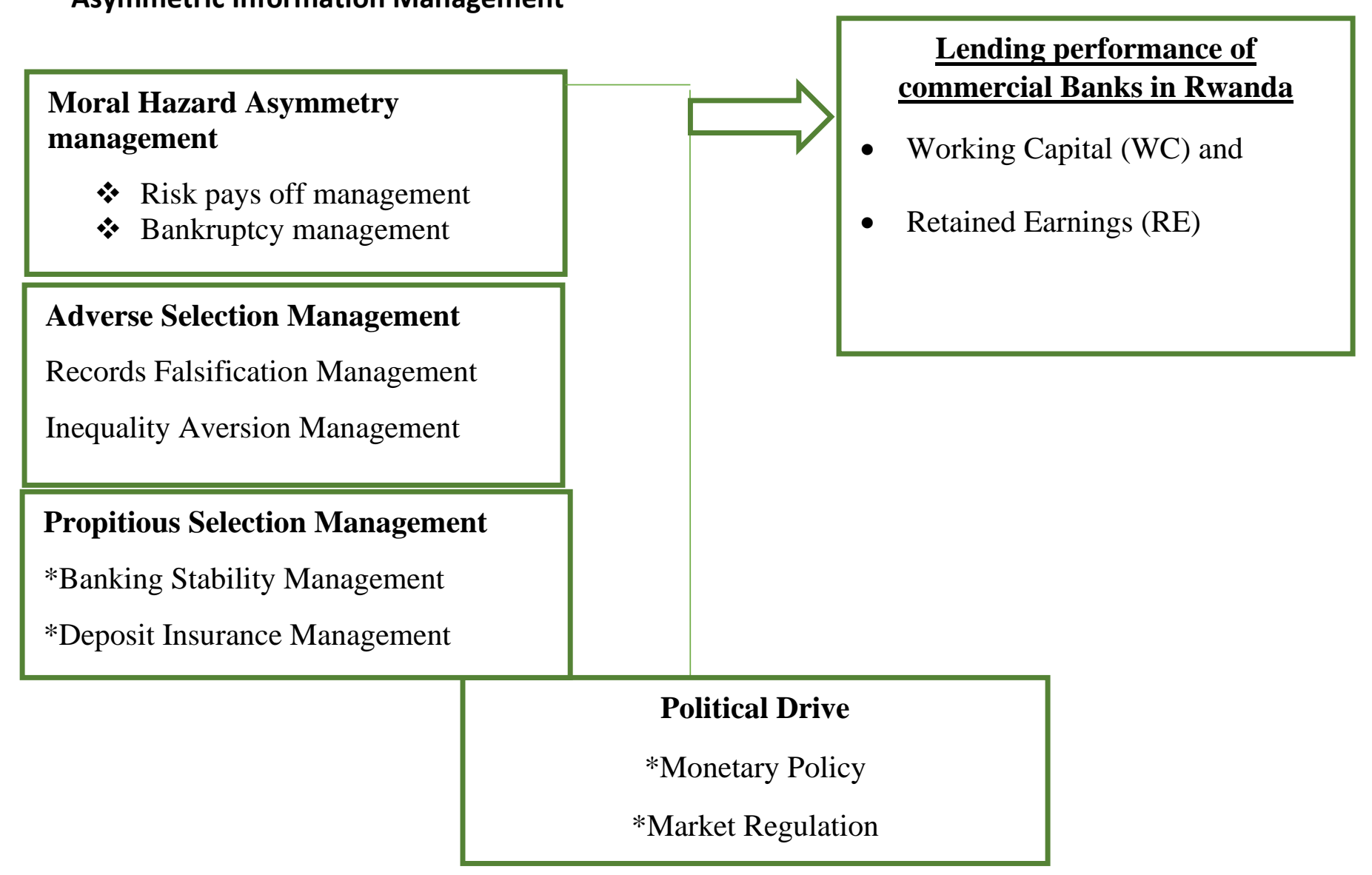




\section{Research Methodology \\ Research design}

The study followed both correlation and comparative designs, and was both qualitative and quantitative.

\section{Target Population}

Population is the study object, which may be individuals, group, organizations human and events, or the conditions to which they are exposed. The population under study was comprised of board of directors, executives, top managers, middle managers and lower managers of 10 strong market leadership in banking sector in Rwanda. The total target population were 931 people.

\section{Sample Frame}

Table 3.1:Sample frame

\begin{tabular}{llll}
\hline Targeted Banks & Target Population & Proportion (\%) & Sample \\
\hline Bank of Kigali & 112 & 12.03 & 33 \\
Bank Populaire du Rwanda & 149 & 16.00 & 44 \\
I \&M Bank & 87 & 9.34 & 26 \\
Cogebanque & 79 & 8.49 & 24 \\
Ecobank & 102 & 10.96 & 30 \\
KCB & 104 & 11.17 & 31 \\
Equity & 63 & 6.77 & 19 \\
GT-Bank & 103 & 11.06 & 31 \\
Access Bank & 68 & 7.30 & 20 \\
CraneBank & 64 & 6.87 & 19 \\
Total & 931 & 100 & 278 \\
\hline
\end{tabular}

Source: (BNR \& Researcher, 2016)

\section{Sample and Sampling Technique}

The sample size is selected using the Yamane formula $=\frac{N}{1+N(e) 2}=\frac{931}{1+931 *(0.05)^{2}}=278$, and then, $n=278$ employees .

\section{Data Collection Instruments.}

The researcher used both primary and secondary data as practical means of obtaining information related to the research topic. The primary data was obtained using questionnaire and interview. Secondary data were sourced from annual reports of 10 selected commercial banks.

\section{Model specification}

\section{Multiple Linear Regression Model}

The study employed a multiple linear regression model given by equation 3.4 below $\boldsymbol{Y}=\boldsymbol{B}_{\boldsymbol{0}}+\boldsymbol{B}_{1} \boldsymbol{X}_{\mathbf{1}}+\boldsymbol{B}_{2} \boldsymbol{X}_{\mathbf{2}}+\boldsymbol{B}_{3} \boldsymbol{X}_{\mathbf{3}}+\boldsymbol{\varepsilon}$ without the moderator, and $Y=\boldsymbol{B}_{0}+\boldsymbol{B}_{1} X_{1} * Z+\boldsymbol{B}_{2} X_{2} * Z+\boldsymbol{B}_{3} X_{3} * Z+\varepsilon$, with the moderator

Where:

i. $\quad \mathrm{Y}$ : Lending performance of commercial banks in Rwanda

ii. $\quad X_{1}$ : moral hazard management

iii. $\quad X_{2}$ : adverse selection management 


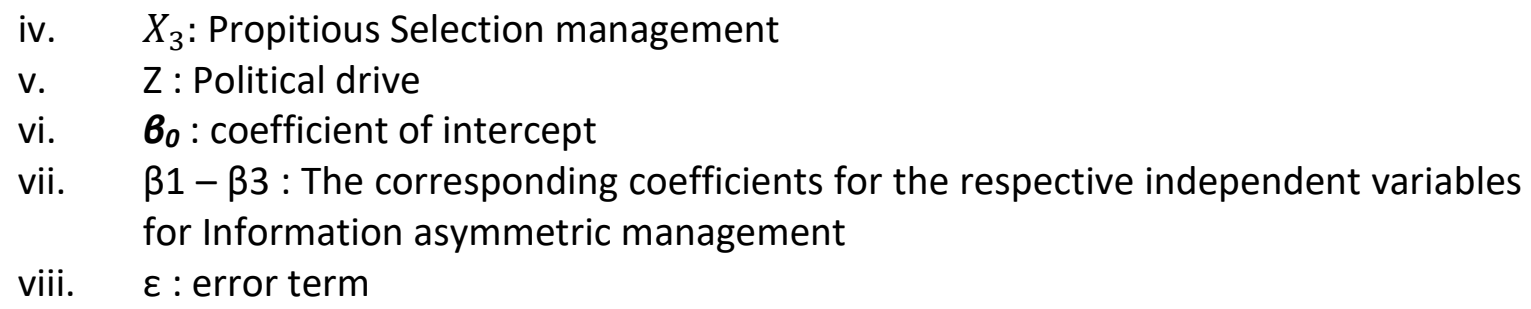

Data Presentation, Analysis, and Interpretation Introduction

This chapter presents the results and findings of the study according to the research objectives and hypotheses. Frequencies mean and percentages were used to analyze data descriptively, while inferential statistics using regression analysis was conducted for the purpose of testing hypothesis and predicting the relationship between the independent and dependent variables.

Figure. 1: Gender of respondents

Level of Education

$$
\begin{aligned}
& \text { Male } \\
& \text { Female }
\end{aligned}
$$

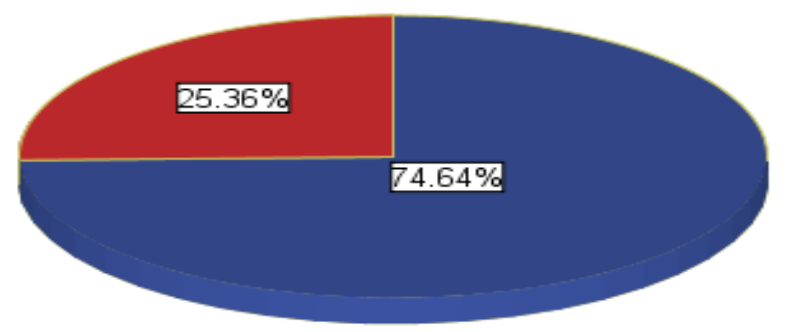

Respondents' qualifications varied greatly with a higher proportion of employees having university-level education at $59.64 \%$, Post University at $40 \%$, and college level at $0.36 \%$. 


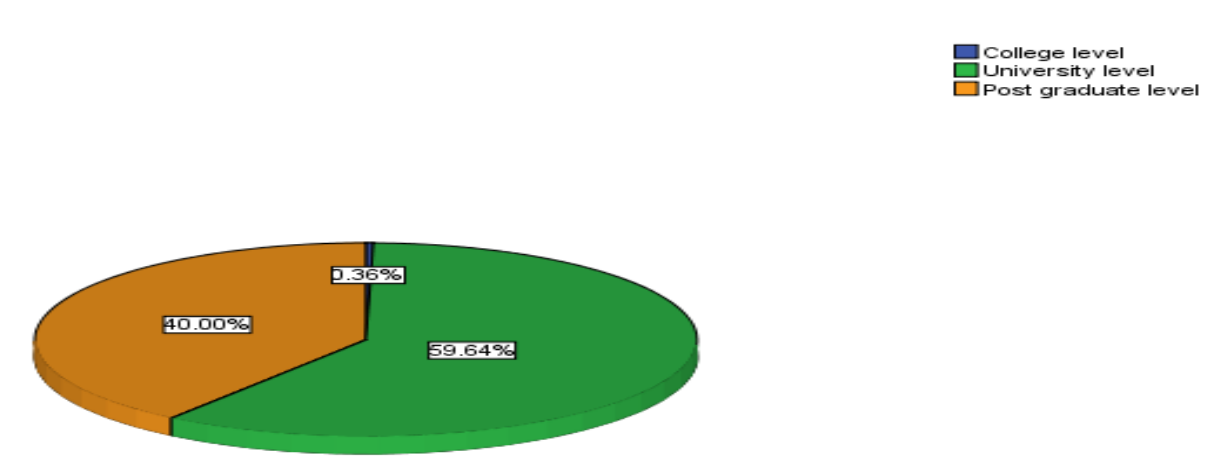

Source: Primary data, 2019

Figure 2: Level of education

Table4. 1 Working experience in commercial banks

Cumulative

Frequency Percent Valid Percent Percent

\begin{tabular}{|c|c|c|c|c|c|}
\hline \multirow[t]{4}{*}{ Valid } & \multicolumn{2}{|c|}{ less than 2 years 4} & 1.4 & 1.4 & 1.4 \\
\hline & 3 to 5 years & 261 & 93.2 & 93.2 & 94.6 \\
\hline & Over 5 years & 15 & 5.4 & 5.4 & 100.0 \\
\hline & Total & 280 & 100.0 & 100.0 & \\
\hline
\end{tabular}

Source: Primary data, 2019

How long has the commercial bank been in operation?

The results from table 4.3 indicate that majority of commercial banks had been in operation over 15 years with $60.4 \%$, followed by 11 to 15 years with $32.5 \%$, lastly 6 to 10 years with $7.1 \%$. 


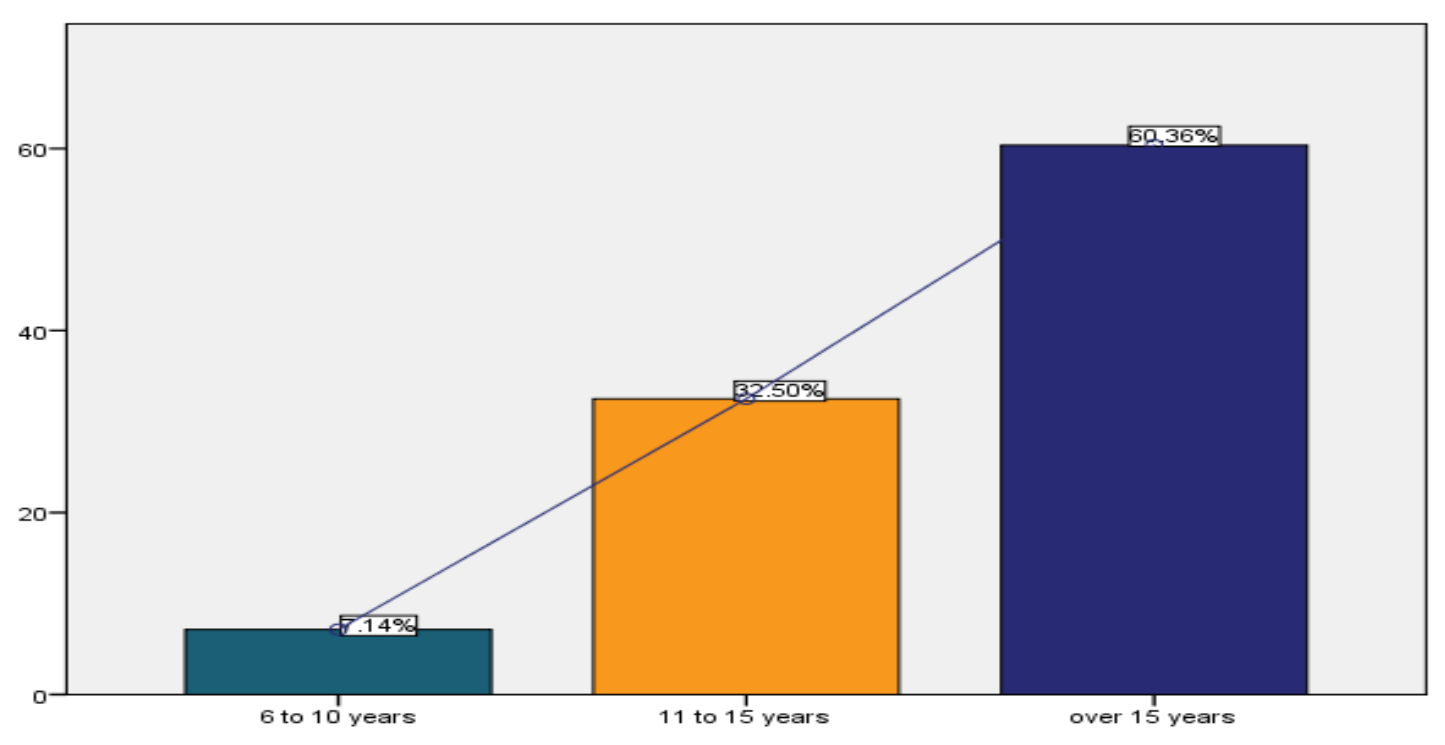

Source: Primary data, 2019

Table 4. 2: Moral hazard management under information asymmetric management indicates the process by which investors latent demands are ultimately translated into prices affect the lending performance of commercial banks in Rwanda

\begin{tabular}{llllll} 
& & & & Cumulative \\
Valid & Strongly agree & 184 & 65.7 & 65.7 & 65.7 \\
& Agree & 87 & 31.1 & 31.1 & 96.8 \\
& Disagree & 4 & 1.4 & 1.4 & 98.2 \\
& Strongly disagree & 5 & 1.8 & 1.8 & 100.0 \\
& & 280 & 100.0 & 100.0 & \\
\hline
\end{tabular}

Source: Primary data, 2019 
Table4. 3: The risks of ell managed as an aspect of moral hazard management information has a positive impact on the investors latent demands and are ultimately translated into volumes of the lending performance of commercial banks in Rwanda

\begin{tabular}{|c|c|c|c|c|c|}
\hline & & Frequency & Percent & Valid Percent & $\begin{array}{l}\text { Cumulative } \\
\text { Percent }\end{array}$ \\
\hline \multirow[t]{5}{*}{ Valid } & Strongly agree & 179 & 63.9 & 63.9 & 63.9 \\
\hline & Agree & 91 & 32.5 & 32.5 & 96.4 \\
\hline & Disagree & 5 & 1.8 & 1.8 & 98.2 \\
\hline & Strongly disagree & 5 & 1.8 & 1.8 & 100.0 \\
\hline & Total & 280 & 100.0 & 100.0 & \\
\hline
\end{tabular}

Source: Primary data, 2019

Table4.4: The bankruptcy management under moral hazard management under information asymmetric management demonstrate and facilitates the ability of market participants to observe information about the trading process which improve the lending performance of commercial banks in Rwanda

\begin{tabular}{llllll}
\hline & & & & Cumulative \\
Valid & Strongly agree & 183 & 65.4 & 65.4 & 65.4 \\
& Agree & 88 & 31.4 & 31.4 & 96.8 \\
& Disagree & 4 & 1.4 & 1.4 & 98.2 \\
Strongly disagree & 5 & 1.8 & 1.8 & 100.0 \\
& & 280 & 100.0 & 100.0 & \\
\hline
\end{tabular}

Source: Primary data, 2019

Table4. 5: Do you think moral hazard under management information asymmetric management with strongly oriented strategies can influence the lending performance in Rwanda?

\begin{tabular}{|c|c|c|c|c|c|}
\hline & & Frequency & Percent & Valid Percent & Cumulative Percent \\
\hline Valid & Yes & 280 & 100.0 & 100.0 & 100.0 \\
\hline
\end{tabular}

Source: Primary data, 2019 
Table4. 6: The adverse selection management under information asymmetric management is primarily concerned with maximizing shareholder value through long-term financial planning is affecting the lending performance of commercial banks in Rwanda

\begin{tabular}{|c|c|c|c|c|c|}
\hline & & Frequency & Percent & Valid Percent & $\begin{array}{l}\text { Cumulative } \\
\text { Percent }\end{array}$ \\
\hline \multirow[t]{5}{*}{ Valid } & Strongly agree & 183 & 65.4 & 65.4 & 65.4 \\
\hline & Agree & 89 & 31.8 & 31.8 & 97.1 \\
\hline & Disagree & 4 & 1.4 & 1.4 & 98.6 \\
\hline & Strongly disagree & 4 & 1.4 & 1.4 & 100.0 \\
\hline & Total & 280 & 100.0 & 100.0 & \\
\hline
\end{tabular}

Source: Primary data, 2019

Table4. 7: The records falsification under the adverse selection under information asymmetric management information is used to control and analyze the previous client's information on different loan taken which should influence the next commercial bank's operations.

\begin{tabular}{llllll}
\hline & & & & Cumulative \\
\hline Valid & Strongly agree & 177 & 63.2 & 63.2 & 63.2 \\
& Agree & 92 & 32.9 & 32.9 & 96.1 \\
& Disagree & 4 & 1.4 & 1.4 & 97.5 \\
& Strongly disagree & 7 & 2.5 & 2.5 & 100.0 \\
Total & 280 & 100.0 & 100.0 & \\
\hline
\end{tabular}

Source: Primary data, 2019

Under information asymmetric management in Rwanda presents numerous opportunities for Financial activities when the financial institutions take into a serious business occasion.

\begin{tabular}{llllll}
\hline & & & & Cumulative \\
\hline Valid & Strongly agree & 181 & 64.6 & 64.6 & 64.6 \\
& $\begin{array}{l}\text { Agree } \\
\text { Disagree }\end{array}$ & 4 & 32.5 & 32.5 & 97.1 \\
& & 1.4 & 1.4 & 98.6 \\
Strongly disagree & 4 & 1.4 & 1.4 & 100.0 \\
Total & 280 & 100.0 & 100.0 & \\
\hline
\end{tabular}

Source: Primary data, 2019 
The results from table 4.12 show that $64.6 \%$ strongly agreed that The inequality aversion managed by the adverse selection management under information asymmetric management in Rwanda present numerous opportunities for Financial activities when the financial institutions take into a serious business occasion, 32.5\% agreed, $1.4 \%$ strongly disagreed while $1.4 \%$ disagreed on the inequality aversion managed by the adverse selection management under information asymmetric management in Rwanda present numerous opportunities for Financial activities when the financial institutions take into a serious business occasion.

Table4. 8: on your experience, does adverse selection management under information asymmetric management has an importance on the lending performance of the commercial bank in Rwanda?

\begin{tabular}{|c|c|c|c|c|c|}
\hline & & Frequency & Percent & Valid Percent & $\begin{array}{l}\text { Cumulative } \\
\text { Percent }\end{array}$ \\
\hline Valid & Yes & 280 & 100.0 & 100.0 & 100.0 \\
\hline
\end{tabular}

Source: Primary data, 2019

Table4. 9: The propitious selection management occurs when risk-avoiding personalities both take physical precautions and buy financial security (insurance) which stabilize the insurance market

\begin{tabular}{llllll}
\hline & & & & Cumulative \\
Valid & Strongly agree & 184 & 65.7 & 65.7 & 65.7 \\
& Agree & 87 & 31.1 & 31.1 & 96.8 \\
& Disagree & 4 & 1.4 & 1.4 & 98.2 \\
& Strongly disagree & 5 & 1.8 & 1.8 & 100.0 \\
& & & & & \\
& Total & 280 & 100.0 & 100.0 &
\end{tabular}

Source: Primary data, 2019 
Table4.10: The banking stability management is used to strengthen the efficiency allocating resources, assessing and managing financial risks, maintaining employment levels close to the economy's natural rate, and eliminating relative price movements of real or financial assets that affect the monetary stability or employment levels.

\begin{tabular}{llllll}
\hline & & & & Cumulative \\
\hline Valid & Strongly agree & 178 & 63.6 & 63.6 & 63.6 \\
& Agree & 93 & 33.2 & 33.2 & 96.8 \\
& Disagree & 4 & 1.4 & 1.4 & 98.2 \\
Strongly disagree & 5 & 1.8 & 1.8 & 100.0 \\
Total & 280 & 100.0 & 100.0 & \\
\hline
\end{tabular}

Source: Primary data, 2019

Table4. 11: the deposit insurance management should be used to ensure all commercial such as saving, fixed, current, recurring, term loan, cash credit, and bills exchange discounting to contribute to the lending performance of commercial banks in Rwanda.

\begin{tabular}{|c|c|c|c|c|c|}
\hline & & Frequency & Percent & Valid Percent & $\begin{array}{l}\text { Cumulative } \\
\text { Percent }\end{array}$ \\
\hline \multirow[t]{5}{*}{ Valid } & Strongly agree & 178 & 63.6 & 63.6 & 63.6 \\
\hline & Agree & 93 & 33.2 & 33.2 & 96.8 \\
\hline & Disagree & 4 & 1.4 & 1.4 & 98.2 \\
\hline & Strongly disagree & 5 & 1.8 & 1.8 & 100.0 \\
\hline & Total & 280 & 100.0 & 100.0 & \\
\hline
\end{tabular}

Source: Primary data, 2019

Table4. 12: On your experience, does propitious selection management contributes to the lending performance of commercial banks in Rwanda?

\begin{tabular}{|c|c|c|c|c|c|}
\hline & & Frequency & Percent & Valid Percent & Cumulative Percent \\
\hline Valid & Yes & 280 & 100.0 & 100.0 & 100.0 \\
\hline
\end{tabular}

Source: Primary data, 2019

The results from table 4.18 illustrate that all respondents $100 \%$ confirmed propitious selection management contributes to the lending performance of commercial banks in Rwanda. 
INTERNATIONAL JOURNAL OF ACADEMIC RESEARCH IN BUSINESS AND SOCIAL SCIENCES Vol. 11, No. 5, 2021, E-ISSN: 2222-6990 @ 2021 HRMARS

Table4. 13: If Yes, which area as illustrated in the table below?

\begin{tabular}{|c|c|c|c|c|c|c|}
\hline & \multicolumn{6}{|c|}{ Cases } \\
\hline & \multicolumn{2}{|c|}{ Included } & \multicolumn{2}{|c|}{ Excluded } & \multicolumn{2}{|l|}{ Total } \\
\hline & $\mathrm{N}$ & Percent & $\mathrm{N}$ & Percent & $\mathrm{N}$ & Percent \\
\hline \multicolumn{7}{|c|}{$\begin{array}{l}\text { Liabilities (current } \\
\text { account, saving account, } 92 \\
\text { fixed and deposits) } \\
\text { insured management }\end{array}$} \\
\hline \multicolumn{7}{|c|}{$\begin{array}{l}\text { Assets (loan, cash in } \\
\text { hands, credit cards, trade } 200 \\
\text { finance and investments) } \\
\text { insurance management }\end{array}$} \\
\hline $\begin{array}{l}\text { other financial asse } \\
\text { (Insurance, investmen } \\
\text { services and mone } \\
\text { transfers) insuranc } \\
\text { management }\end{array}$ & 92 & $32.9 \%$ & 188 & $67.1 \%$ & 280 & $100.0 \%$ \\
\hline $\begin{array}{l}\text { other propitiou } \\
\text { selection management }\end{array}$ & 4 & $1.4 \%$ & 276 & $98.6 \%$ & 280 & $100.0 \%$ \\
\hline
\end{tabular}

Source: Primary data, 2019 
Table4. 14: The political drive well oriented to the national interest has a positive effect on lending performance management on the lending performance of commercial banks in Rwanda.

$\begin{array}{lllll} & & & & \text { Cumulative } \\ & \text { Frequency } & \text { Percent } & \text { Valid Percent } & \begin{array}{l}\text { Percent } \\ \text { Valid }\end{array} \text { Strongly agree } \\ & 183 & 65.4 & 65.4 & 65.4\end{array}$

Agree

$\begin{array}{llll}87 & 31.1 & 31.1 & 96.4\end{array}$

Disagree

$\begin{array}{llll}4 & 1.4 & 1.4 & 97.9\end{array}$

Strongly disagree

$\begin{array}{llll}6 & 2.1 & 2.1 & 100.0\end{array}$

Total

$280 \quad 100.0 \quad 100.0$

Source: Primary data, 2019

Table4. 15: The market regulation management under the political drive is the main aspect that provides the government to regulate the commercial banks' lending performance in Rwanda.

\begin{tabular}{|c|c|c|c|c|c|}
\hline & & Frequency & Percent & Valid Percent & $\begin{array}{l}\text { Cumulative } \\
\text { Percent }\end{array}$ \\
\hline \multirow[t]{5}{*}{ Valid } & Strongly agree & 180 & 64.3 & 64.3 & 64.3 \\
\hline & Agree & 88 & 31.4 & 31.4 & 95.7 \\
\hline & Disagree & 5 & 1.8 & 1.8 & 97.5 \\
\hline & Strongly disagree & 7 & 2.5 & 2.5 & 100.0 \\
\hline & Total & 280 & 100.0 & 100.0 & \\
\hline
\end{tabular}

Source: Primary data, 2019 
Table4. 16: The value like interest rate well determined should facilitate the equilibrium strategies on both clients and providers of lending performance of commercial banks

\begin{tabular}{|c|c|c|c|c|c|}
\hline & & Frequency & Percent & Valid Percent & $\begin{array}{l}\text { Cumulative } \\
\text { Percent }\end{array}$ \\
\hline \multirow[t]{5}{*}{ Valid } & Strongly agree & 179 & 63.9 & 63.9 & 63.9 \\
\hline & Agree & 92 & 32.9 & 32.9 & 96.8 \\
\hline & Disagree & 4 & 1.4 & 1.4 & 98.2 \\
\hline & Strongly disagree & 5 & 1.8 & 1.8 & 100.0 \\
\hline & Total & 280 & 100.0 & 100.0 & \\
\hline
\end{tabular}

Source: Primary data, 2019

Table4. 17: The economic growth benefit of higher living standards, real incomes, and ability to devote more resources improved the lending performance of the commercial bank in Rwanda

\begin{tabular}{llllll}
\hline & & & & Cumulative \\
\hline Valid & Strongly agree & 183 & 65.4 & 65.4 & 65.4 \\
& Agree & 88 & 31.4 & 31.4 & 96.8 \\
& Disagree & 4 & 1.4 & 1.4 & 98.2 \\
& Strongly disagree & 5 & 1.8 & 1.8 & 100.0 \\
& Total & 280 & 100.0 & 100.0 & \\
\hline
\end{tabular}

Source: Primary data, 2019

Table4. 18: The services in the largest sector of the Rwanda economy and accounts for 53 percent of total Working Capital (WC) that improve not only the commercial bank's income but also the client's benefit

\begin{tabular}{|c|c|c|c|c|c|}
\hline & & Frequency & Percent & Valid Percent & $\begin{array}{l}\text { Cumulative } \\
\text { Percent }\end{array}$ \\
\hline \multirow[t]{5}{*}{ Valid } & Strongly agree & 182 & 65.0 & 65.0 & 65.0 \\
\hline & Agree & 89 & 31.8 & 31.8 & 96.8 \\
\hline & Disagree & 4 & 1.4 & 1.4 & 98.2 \\
\hline & Strongly disagree & 5 & 1.8 & 1.8 & 100.0 \\
\hline & Total & 280 & 100.0 & 100.0 & \\
\hline
\end{tabular}

Source: Primary data, 2019 
Table4. 19: The important Retained Earnings(RE) fix at the natural level in the basis attraction for the FDI which impacts the lending performance of commercial banks in Rwanda.

\begin{tabular}{llllll}
\hline & & & & Cumulative \\
Valid & Strongly agree & 180 & 64.3 & 64.3 & 64.3 \\
& Agree & 91 & 32.5 & 32.5 & 96.8 \\
& Disagree & 4 & 1.4 & 1.4 & 98.2 \\
& Strongly disagree & 5 & 1.8 & 1.8 & 100.0 \\
& & 280 & 100.0 & 100.0 & \\
\hline
\end{tabular}

Source: Primary data, 2019

Table4. 20: contribution of information Asymmetric management on the lending performance of commercial banks in Rwanda (Working Capital (WC))

- Dependent Variable: Lending performance of commercial banks in Rwanda(GDP per capita)

Sample: 280

Included Observations: 280

\begin{tabular}{|c|c|c|c|c|c|}
\hline \multirow[t]{2}{*}{ I. Variable: FPS } & \multicolumn{2}{|c|}{ Coefficient } & \multirow{2}{*}{$\begin{array}{l}\text { Std. Coefficient } \\
\text { Beta }\end{array}$} & \multirow{2}{*}{$\begin{array}{l}\text { t- } \\
\text { Statictire }\end{array}$} & \multirow[t]{2}{*}{ Prob. } \\
\hline & B & Std. Error & & & \\
\hline 1(Constant) & 2.603 & 0.22 & & 11.274 & 0.000 \\
\hline $\begin{array}{l}\text { Moral hazard } \\
\text { management }\end{array}$ & 0.701 & 0.15 & 0.017 & 3.262 & 0.031 \\
\hline $\begin{array}{ll}\text { Adverse } & \text { selection } \\
\text { management } & \end{array}$ & 0.600 & 0.09 & 0.009 & 3.389 & 0.040 \\
\hline $\begin{array}{l}\text { propitious Selection } \\
\text { information asymmetric } \\
\text { management } \\
\text { management }\end{array}$ & 0.808 & 0.013 & 0.901 & 8.197 & 0.001 \\
\hline $\mathbf{R}$ & 0.796 & & Mean dependen & & 1.877 \\
\hline R-squared & 0.796 & & S.D. dependent & & 0.685 \\
\hline
\end{tabular}




\begin{tabular}{|l|l|l|l|}
\hline Adjusted R-squared & 0.701 & Durbin-Watson statistics & 1.766 \\
\hline F-statistics & 6.214 & Standard Error of Estimate & 0.256 \\
\hline Prob (F-statistic) & 0.003 & & \\
\hline
\end{tabular}

Source: Survey Data 2019

\section{Conclusions}

In conclusion, the researcher brought out the summary based on the findings by demonstrating the role of each independent variable vis-à-vis to the dependent variable and its indicators for instance Working Capital (WC) and Retained Earnings (RE). Besides, this conclusion demonstrates the findings based on the level of contribution of each Information asymmetric management pillars according to the two indicators of Working Capital (WC) and Retained Earnings (RE).

Conclusion on the contribution of the propitious selection management on the lending performance of Commercial Banks in Rwanda.

The researcher findings demonstrate that propitious selection management contributes to the lending performance of Commercial Banks in Rwanda. where the econometrics and statistical analysis shows the ties contribution of propitious selection management with $\beta=$ 0.873 on Working Capital (WC) and $\beta=0.874$ Retained Earnings (RE). With $p$-value $0.03<0.05$,

Conclusion of the effect of political drive on the influence of information asymmetry management on the lending performance of Commercial Banks in Rwanda

The researcher findings demonstrate that political drive has a positive influence on information asymmetry management on the lending performance of Commercial Banks in Rwanda; where econometrics and statistical analysis shows positive contribution with $B=0.783$ on Working Capital (WC) and $B=0.789$ on Retained Earnings (RE).

Conclusion on moral hazard management on the lending performance of Commercial Banks in Rwanda.

The researcher findings demonstrate that moral hazard management has tied influence on the lending performance of Commercial Banks in Rwanda; where econometrics and statistical analysis shows positive contribution with $B=0.783$ on Working Capital (WC) and $B=0.789$ on Retained Earnings (RE).

The researcher findings demonstrate that $100 \%$ of respondents confirmed that moral hazard management has contributed to the lending performance of Commercial Banks in Rwanda. With a p-value of $0.003<0.05$.

Conclusion on the effect of adverse selection management and lending performance of Commercial Banks in Rwanda.

The researchers' findings demonstrate that the adverse selection management plays a positive role in the lending performance of Commercial Banks in Rwanda. The findings 
showed that $100 \%$ of respondents confirmed that adverse selection management has an effect on the lending performance of Commercial Banks in Rwanda. The statistical analysis shows the positive contribution of adverse selection management on lending performance of Commercial Banks in Rwanda. with $B=0.685$ on Working Capital (WC) and $B=0.589$ on Retained Earnings (RE). With p-value 0.002<0.05.

\section{Significance of the Study}

This study is important to various stakeholders in particular the Government of Rwanda, financial institutions, Commercial Banks in specific, different academicians, professionals, and researchers. In this work, the researcher aimed at developing the notion conceptually. Specifically, the researcher built on the work of (Richard, 2006), where the pillars determined such as Moral Hazard management, Adverse Selection management, and Propitious Selection management. That influenced the lending performance of Commercial Banks in Rwanda.

\section{Recommendations}

Based on the results, findings, and conclusions on the Study, the outlines of recommendations were determined. This was done in view of the study objectives.

Recommendations on the contribution of Propitious Selection management on the lending performance of Commercial Banks in Rwanda;

The study recommends that the government of Rwanda should diversify the Propitious Selection management policy and monetary regulation to make sure its influence becomes strong maintain and visible in order to ensure lending provided by Commercial Banks in Rwanda are well performance.

Recommendations on the effect of political drive on the influence of information asymmetric management and lending performance of Commercial Banks in Rwanda.

The Researcher recommends that the Government of Rwanda's Monetary policy and Financial Market Regulation on the Lending performance of commercial banks and its application should be more friendly and attractive to local and foreigners' business actors.

\section{Recommendations on the influence of moral hazard management and lending performance of Commercial Banks in Rwanda;}

The Researcher, recommends that the Government of Rwanda and Civil society should diversify the moral hazard management with all financial bodies to accomplish these mentioned gaps.

The Researcher recommends that a monitoring of Rwanda's lending financial performance on a regular basis should be taken into consideration in order to understanding trends, patterns in the financial aspect and provides an opportunity to highlight emerging issues on both business components.

Recommendations on the importance of adverse selection management on the lending performance of Commercial Banks in Rwanda

The Researcher recommends that financial institutions and Civil society to diversify the adverse selection management by change the mechanism and strategies used to make sure is well oriented to the positive influence to achieve the Working Capital (WC) and Retained Earnings (RE) operation. 
The Rwandan Financial sector and civil society understand the government policy and strategies to maintain financial partnership support the implementation of adverse selection management on achieving on the lending performance of Commercial Banks in Rwanda

\section{REFERENCES}

Abdi, D. (2010). FINANCIAL PERFORMANCE EVALUATION (A Case Study of Awash International Bank (AIB): A Research project submitted to the Department of Accounting and Finance, College of Business and Economics, Mekelle University, for the partial Fulfillment.

Acharya, V. M., \& Thakor, A. (2015). Caught between Scylla and Charybdis? Regulating Bank Leverage When There Is Rent Seeking and Risk Shifting', Review of Corporate FinanceStudies, 5 (1), pp. 36-75.

Acharya, V. V., \& Saunders, A. (2006). Should Banks Be Diversified? Evidence from Individual Bank Loan Portfolios. The Journal of Business, 79(3), 1355-1412.

AFDB. (2018). East Africa Economic Outlook 2018: African Development Bank 2018; ISBN 9789938-882-68-1.

AfDB Group. (2014). Improving economic competitiveness to bring about shared growth. The African Development Bank Group and Rwanda four decades of Partnership;

AFSA, M. (2015). WORKING CAPITAL MANAGEMENT AND THE PERFORMANCE OF COMMERCIAL BANKS IN RWANDA:A Research Project Submitted in Partial Fulfillment of the Master of Business Administration(Finance; A Case study of Fina Bank main branch, Nyarugenge District-Kigali City.

Afzal, A., \& Mirza, N. (2012). Size, Diversification and Risk: Preliminary Evidence from Commercial Banks in Pakistan. Pakistan Journal of Commerce Social Sciences, 6(2), 282-296.

Agoraki, M. D., \& Pasiouras, F. (2011). Regulations, competition and bank risk-taking in transitioncountries" Journal of Financial Stability, Vol. 7 No. 1, pp. 38-48.

Aikaeli, J. (2008). Commercial bank efficiency in Tanzania. A paper presented at a CSAE Conference on Economic Development in Africa, held at St. Catherine's College, Oxford, 16th - 18th. . 